\title{
Cocaine Increases the Intracellular Calcium Concentration in Brain Independently of Its Cerebrovascular Effects
}

\author{
Congwu Du, ${ }^{1,5}$ Mei Yu, ${ }^{1}$ Nora D. Volkow, ${ }^{3}$ Alan P. Koretsky, ${ }^{4}$ Joanna S. Fowler, ${ }^{2}$ and Helene Benveniste ${ }^{1,5}$ \\ ${ }^{1}$ Medical Department and ${ }^{2}$ Department of Chemistry, Brookhaven National Laboratory, Upton, New York 11973-5000, ${ }^{3}$ National Institute on Alcohol Abuse \\ and Alcoholism and ${ }^{4}$ Laboratory of Functional and Molecular Imaging, National Institute of Neurological Disorders and Stroke, National Institutes of \\ Health, Bethesda, Maryland 20892, and ${ }^{5}$ Department of Anesthesiology, State University of New York at Stony Brook, Stony Brook, New York $11794-8700$
}

Cocaine abuse increases the risk of life-threatening neurological complications such as strokes and seizures. Although the vasoconstricting properties of cocaine underlie its cerebrovascular effects, the mechanisms underlying its neurotoxicity remain incompletely understood. Here, we use optical techniques to measure cerebral blood volume, hemoglobin oxygenation $\left(\mathrm{S}_{\mathrm{t}} \mathrm{O}_{2}\right)$, and intracellular calcium $\left(\left[\mathrm{Ca}^{2+}\right]_{\mathrm{i}}\right)$ to test the hypothesis that cocaine increases $\left[\mathrm{Ca}^{2+}\right]_{\mathrm{i}}$ in the brain. The effects of cocaine were compared with those of methylphenidate, which has similar catecholaminergic effects as cocaine (except for serotonin increases) but no local anesthetic properties, and of lidocaine, which has similar local anesthetic effects as cocaine but is devoid of catecholaminergic actions. To control for the hemodynamic effects of cocaine, we assessed the effects of cocaine in animals in which normal blood pressure was maintained by infusion of phenylephrine, and we also measured the effects of transient hypotension (mimicking that induced by cocaine). We show that cocaine induced significant increases $(\sim 10-15 \%)$ in $\left[\mathrm{Ca}^{2+}\right]_{\mathrm{i}}$ that were independent of its hemodynamic effects and of the anesthetic used (isofluorance or $\alpha$-chloralose). Lidocaine but not methylphenidate also induced significant $\left[\mathrm{Ca}^{2+}\right]_{\mathrm{i}}$ increases $(\sim 10-13 \%)$. This indicates that cocaine at a dose within the range used by drug users significantly increases the $\left[\mathrm{Ca}^{2+}\right]_{\mathrm{i}}$ in the brain and its local anesthetic, but neither its catecholaminergic nor its hemodynamic actions, underlies this effect. Cocaine-induced $\left[\mathrm{Ca}^{2+}\right]_{i}$ increases are likely to accentuate the neurotoxic effects from cocaine-induced vasoconstriction and to facilitate the occurrence of seizures from the catecholaminergic effects of cocaine. These findings support the use of calcium channel blockers as a strategy to minimize the neurotoxic effects of cocaine.

Key words: cocaine; cerebrovascular; calcium; blood volume; oxygenation; neurotoxicity

\section{Introduction}

The abuse of cocaine can lead to transient cerebral ischemia, stroke, and hemorrhages, which are believed to reflect the vasoconstricting effects of cocaine (Volkow et al., 1988; Martin et al., 1994; Johnson et al., 2001; Buttner et al., 2003; Bartzokis et al., 2004; Bolouri et al., 2004; Wilson et al., 2004). The vasoactive properties of cocaine are well known clinically and are taken advantage of when it is used as a local anesthetic (De et al., 2003). Indeed, studies have shown that cocaine reduces cerebral blood flow (CBF) and blood volume in human subjects and in laboratory animals (Volkow et al., 1988; Pearlson et al., 1993; Wallace et al., 1996; Schmidt et al., 2006). Cocaine has multiple pharmacological targets including blockade of the dopamine, serotonin, and norepinephrine transporters (Ritz et al., 1987) that give it its sympathomimetic effects and blockade of sodium channels,

Received March 20, 2006; revised Sept. 24, 2006; accepted Sept. 25, 2006.

This work was supported by Laboratory Directed Research and Development Grants 02-08 (H.B.) and 04-066 (C.D.), Brookhaven National Laboratory, Department of Energy Office of Science and Biological Research, and New York State Office of Science, Technology, and Academic Research. We thank Dr. P. Thanos for valuable discussions regarding the pharmacokinetics and pharmacodynamics of cocaine and methylphenidate.

Correspondence should be addressed to either Dr. Helene Benveniste or Dr. Congwu Du at the above address. E-mail: Benveniste@bnl.gov or congwu@bnl.gov.

DOI:10.1523/JNEUROSCI.3612-06.2006

Copyright $\odot 2006$ Society for Neuroscience $\quad 0270-6474 / 06 / 2611522-10 \$ 15.00 / 0$ which gives it its local anesthetic actions (Gissen et al., 1980). Cocaine-induced reductions in CBF could reflect (1) direct vasoconstrictive effects elicited via increases in intracellular calcium $\left(\left[\mathrm{Ca}^{2+}\right]_{\mathrm{i}}\right)$ in vascular smooth muscle (Zhang et al., 1996), (2) indirect vasconstriction secondary to increases of sympathomimetic amines, or (3) an indirect consequence of reduced neural activity and metabolic demand attributable to blockade of sodium channels. Additionally, one must also consider the impact of the peripheral hemodynamic effects of cocaine. For example, cocaine elicits an increase in cerebrovascular resistance and a decrease in carotid blood flow (Stankovic et al., 1998) and an increase in blood pressure. In addition, repeated cocaine administration has been shown to increase voltage-sensitive calcium currents in response to membrane depolarization in prefrontal cortex pyramidal neurons (Uchimura and North, 1990; White and Kalivas, 1998; Trantham-Davidson and Lavin, 2004; Nasif et al., 2005). These data combined with the well known role of intracellular calcium as a "final common pathway to cell death" (Schanne et al., 1979) led us to hypothesize that the toxic effects of cocaine in the brain may in part be related to changes in $\left[\mathrm{Ca}^{2+}\right]_{\mathrm{i}}$.

Noninvasive imaging techniques such as positron emission tomography (London et al., 1990; Volkow et al., 1992, 1996) and magnetic resonance imaging (MRI) (Breiter et al., 1997; Breiter and Rosen, 1999; Mandeville et al., 2001; Lee et al., 2003) have 
Table 1. Animal groups and experimental design

\begin{tabular}{llll}
\hline Group & Intravenous drug challenge & Anesthetic & Hemodynamic intervention \\
\hline $1(n=4)$ & Vehicle $(0.9 \% \mathrm{NaCl}, 0.1 \mathrm{cc} / 100 \mathrm{mg})$ & Isoflurane & No \\
$2 \mathrm{a}(n=6)$ & Cocaine hydrochloride $(1 \mathrm{mg} / \mathrm{kg})$ & Isoflurane & No \\
$2 \mathrm{~b}(n=3)$ & Cocaine hydrochloride $(1 \mathrm{mg} / \mathrm{kg})$ & $\alpha$-Chloralose & No \\
$3(n=5)$ & Methylphenidate hydrochloride $(1 \mathrm{mg} / \mathrm{kg})$ & Isoflurane & No \\
$4(n=6)$ & Lidocaine hydrochloride $(1 \mathrm{mg} / \mathrm{kg})$ & Isoflurane & No \\
$5(n=4)$ & No & Isoflurane & Yes, blood withdrawal to maintain MABP \\
& & & at 40 - 50 mmHg for 4 min \\
$6(n=5)$ & Cocaine hydrochloride $(1 \mathrm{mg} / \mathrm{kg})$ & Isoflurane & Yes, intravenous phenylephrine to \\
& & & maintain MABP within a normal \\
& & & range (70 - 90 mmHg) during the
\end{tabular}

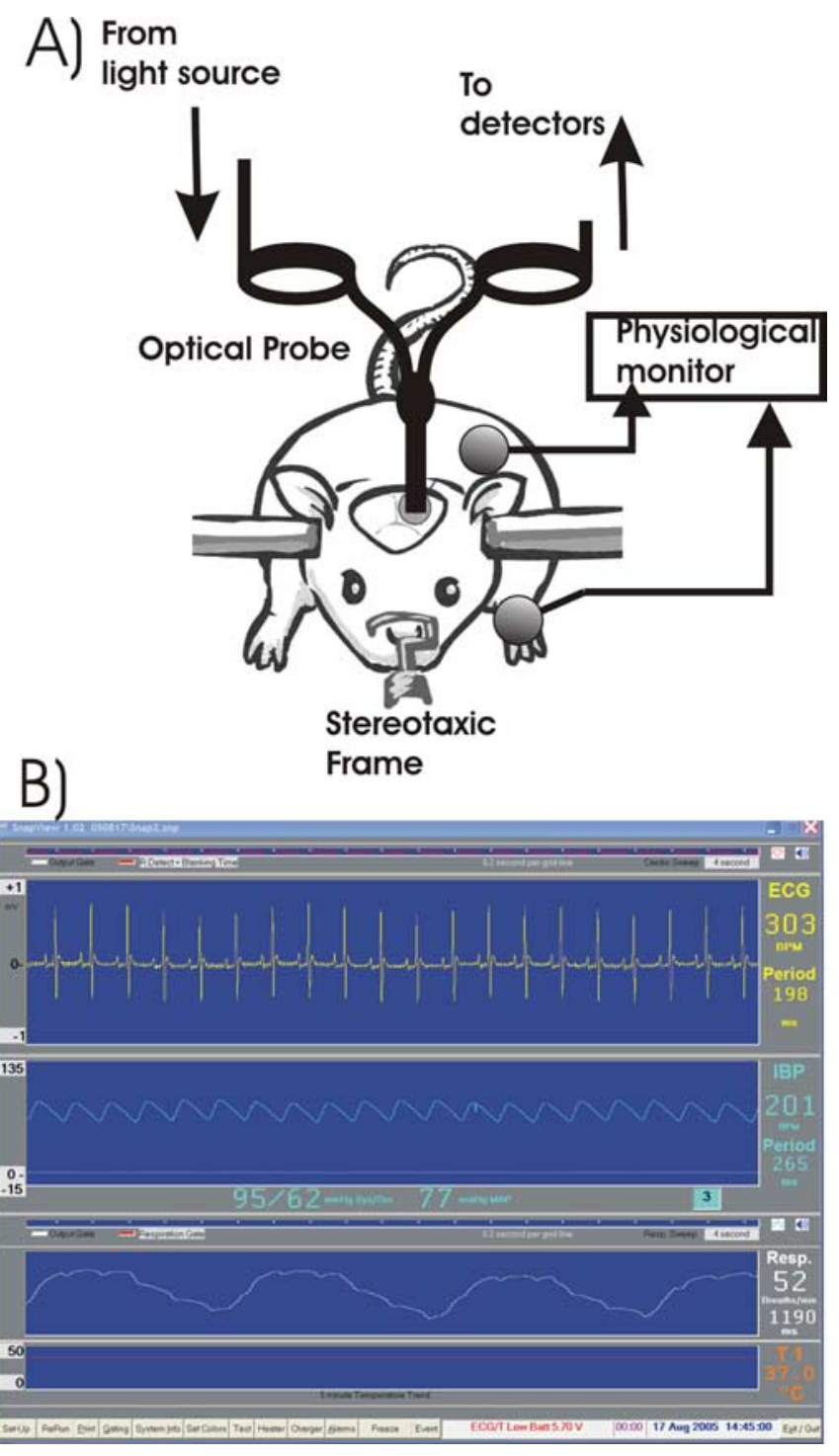

Figure 1. A, Schematic illustration of the optical diffusion fluorescence experimental setup used for all studies. $\boldsymbol{B}$, Example of a real-time physiological monitoring acquired during experiments.

been used to investigate the effects of cocaine in the human brain and in animals. Optical techniques have also been used to monitor the cerebrovascular and functional effects of cocaine in animals (Stankovic et al., 1998; Devonshire et al., 2004; Berwick et al., 2005). One advantage of optical technology is that it can concurrently detect oxyhemoglobin and deoxyhemoglobin, thereby distinguishing changes in the total hemoglobin concentration and oxygenation (Jobsis, 1977; Chance et al., 1988; Cope and Delpy, 1988). In addition, fluorescence techniques can directly access $\left[\mathrm{Ca}^{2+}\right]_{\mathrm{i}}$ in the brain. Fluorescent indicators (e.g., Rhod2) are administered as acetoxymethyl esters that readily penetrate cell membranes and inside the cell are hydrolyzed to form the calcium-binding indicator, which is membrane impermeable (Grynkiewicz et al., 1985; Minta et al., 1989). Exposure to light of the appropriate wavelength induces fluorescence emission that depends on $\left[\mathrm{Ca}^{2+}\right]_{\mathrm{i}}$ (Del Nido et al., 1998; Du et al., 2001a,b). Most optical experiments have used either isolated cells or brain slices (Kudo et al., 1992; Takahashi et al., 1993; Helmchen and Waters, 2002). We recently developed a fiber optic-based optical catheter that enables simultaneous detection of changes in $\left[\mathrm{Ca}^{2+}\right]_{\mathrm{i}}$ as well as hemoglobin concentrations and oxygenation from the cortex of the living rat (Du et al., 2005).

Here, we test the hypothesis that the toxic effects of cocaine are not just the result of its cerebrovascular effects but also its ability to increase $\left[\mathrm{Ca}^{2+}\right]_{\mathrm{i}}$. For this purpose, we use our new optical technique to measure changes in the concentration and oxidation states of hemoglobin, concurrently with Rhod2-Ca fluorescence (representing $\left[\mathrm{Ca}^{2+}\right]_{\mathrm{i}}$ ) in the living brain during administration of cocaine. To assess whether the effects of cocaine on $\left[\mathrm{Ca}^{2+}\right]_{i}$ were attributable to its sympathomimetic and/or local anesthetic properties, we compared the response to that of methylphenidate [a drug with sympathomimetic effects similar to cocaine, except for serotonin increases, but with no local anesthetic properties (Volkow et al., 1999)] and lidocaine [a local anesthetic devoid of catecholaminergic actions (Woodward et al., 1995)], respectively. In parallel, we also measured cerebral blood volume $(\mathrm{CBV})$, blood pressure, and heart rate to assess whether the increases of cocaine in $\left[\mathrm{Ca}^{2+}\right]_{\mathrm{i}}$ in the brain occurred independently of its peripheral hemodynamic changes.

\section{Materials and Methods}

Subjects. All experimental procedures were approved by the Institutional Animal Care and Use Committee. Thirty-three female Sprague Dawley rats $(250-350 \mathrm{~g})$ were divided into experimental groups as shown in Table 1.

Animal preparation. All animals were induced with 3\% isoflurane, intubated, and mechanically ventilated (Inspira asv; Harvard Apparatus, Holliston, MA). Anesthesia was maintained with $1.5-2 \%$ isoflurane in a $60-70 \% \mathrm{O}_{2}$ /air mixture. The femoral artery was cannulated for continuous arterial blood pressure monitoring, and the femoral vein was catheterized for administration of drugs. The anesthetized rat was then positioned in a stereotaxic frame (frame number 9; Kopf Instruments, Tujunga, CA), and an $\sim 3 \mathrm{~mm}$ left craniotomy was made above the area of the parietal cortex, which corresponds in part to the hindlimb somatosensory area (the craniotomy center positioned $\approx 2 \mathrm{~mm}$ behind and 2 $\mathrm{mm}$ lateral to bregma). The electrocardiogram, intra-arterial blood pressure, respiratory rate, and body temperature were continuously recorded (module 224002; Small Animal Instruments, Stony Brook, NY). Blood gases were monitored regularly to keep $\mathrm{PaCO}_{2}$ in the range of 30-45 $\mathrm{mmHg}$ during the experiments. Figure $1 A$ illustrates the schematic of the experimental animal setup, and Fig. $1 B$ shows an example of the physiological monitoring output in real time. Except for group $2 b$, all animals were maintained with isoflurane anesthesia at $1.8-2 \%$ during the experimental protocol. In group $2 \mathrm{~b}$ rats, the anesthesia was switched from 
isoflurane to $\alpha$-chloralose with careful attention to anesthetic depth and hemodynamics at the time of Rhod2 loading (see below). The $\alpha$-chloralose was delivered through the venous catheter using an initial dose of $40 \mathrm{mg} / \mathrm{kg} / \mathrm{h}$, followed by a constant infusion of $27 \mathrm{mg} / \mathrm{kg} / \mathrm{h}$. We included this group of animals to ensure that the findings were not attributable to the hemodynamic effects of cocaine in isofluraneanesthetized animals (see below).

Rhod2 loading. Fifty micrograms of the fluorescence calcium indicator Rhod2 acetoxymethyl ester (Rhod2/AM) (R-1243; Invitrogen, Eugene, OR) were dissolved in $2 \mu \mathrm{l}$ of dimethylsulfoxide and $440 \mu \mathrm{l}$ of distilled water at room temperature. A $30 \mathrm{~g}$ needle attached to a stereotaxic micromanipulator was inserted into the somatosensory cortex $1.2-1.5 \mathrm{~mm}$ below the surface at an angle of $\sim 45^{\circ}$ to the surface with the needle tip starting at the center of the craniotomy. The Rhod 2 solution was infused into the brain at a perfusion flow rate of $3 \mu \mathrm{l} / \mathrm{min}$ using a microinjection pump (CMA/100; Carnegie Medicine, Stockholm, Sweden). A total volume of $100 \mu \mathrm{l}$ of the Rhod2 solution was infused. After Rhod2 loading, the optical probe was positioned onto the exposed cortex area (Fig. 1A), and baseline recordings were made for 60-80 $\mathrm{min}$.

Experimental protocol. After the optical baseline recordings (to allow for Rhod2 diffusion and hydrolysis), vehicle (group 1), cocaine hydrochloride (groups 2a and 2b), methylphenidate hydrochloride (group 3), or lidocaine hydrochloride (group 4 ) was quickly injected $(<10 \mathrm{~s})$ via the femoral vein. The intravenous line was flushed with $1 \mathrm{cc}$ of $0.9 \% \mathrm{NaCl}$ before and after the injection (Fig. $2 B$ ), which induced transient, small optical signal increases that were later used as temporal "landmarks" to coregister the experiments from individual animals for statistical analysis (see below, Optical data acquisition and analysis). In group 5, exsanguination of 2-3 cc of blood from the arterial line was performed to transiently ( $\approx 4 \mathrm{~min}$ ) reduce the mean arterial blood pressure (MABP) to 40-50 $\mathrm{mmHg}$. This experimental group was added to mimic the hemodynamic changes (transient mild hypotension to $40-50 \mathrm{mmHg}$ ) that occurred in the isoflurane-anesthetized group $2 \mathrm{a}$ rats during the cocaine challenge. Group 6 rats received phenylephrine $(0.1-0.3 \mathrm{mg} / \mathrm{h})$ after intravenous cocaine to maintain the MABP within normal limits.

Optical diffusion and fluorescence detection instrument. We used a catheter-based optical diffusion and fluorescence instrument that has been described previously (Du et al., 2005). Briefly, it consisted of a 150 $\mathrm{W}$ xenon lamp, a fast excitation monochromator, and the photocounting detectors for fluorescence (PMT-F) and diffuse reflectance (PMT-A). The lamp was connected to the computer-controlled monochromator to select the incident lights of 548,555 , and $572 \mathrm{~nm}$ by timesharing to sequentially deliver the selected lights onto the brain surface through one arm of a Y-shaped bifurcated fiber-optic bundle (Fig. 1A). The fluorescence and the diffuse-reflected light re-emitted from the brain tissue were collected by the fiber optic tip of the common leg and transferred through the outgoing leg of the bundle. After passing through a beam splitter, $5 \%$ of the signal intensity was reflected by a dichroic cube for detection by PMT-A, whereas $95 \%$ was delivered to PMT-F for fluorescence detection. A bandpass filter centered at $589 \mathrm{~nm}$ with $\pm 10 \mathrm{~nm}$ bandwidth is placed in front of PMT-F to define the fluorescence emission at $589 \mathrm{~nm}$. A filter cube in front of PMT-F was synchronized with the monochromator to pass the fluorescence emission through while being excited at $548 \mathrm{~nm}$ but block the incident light at 555 and $572 \mathrm{~nm}$. The scattered re-emission (i.e., diffuse photon reflection) at 548, 555, and 572 $\mathrm{nm}$ from the brain tissue were detected by PMT-A. The signals were digitized and stored in a personal computer for data processing.

Optical data acquisition and analysis. To detect the calcium fluorescence and diffuse reflectance from the cortex, the optical fiber tip was placed in contact with the cortical surface as shown in Figure $1 A$. The interface between the fiber optic and the exposed brain surface was filled with gel (Surgical Lubricant Sterile Bacteriostatic; E. Fougera, Melville, $\mathrm{NY}$ ) to reduce the mismatch in refractive index between optical fiber, air, and brain tissue, thus minimizing the interface specular reflection from the surface of the brain. Figure $2 A$ illustrates the absorbance and Rhod 2 excitation spectra obtained simultaneously from the cortex. The center wavelengths of excitations (referred to as $\lambda \operatorname{ex} 1, \lambda \operatorname{ex} 2$, and $\lambda \operatorname{ex} 3$ by dashed lines) and fluorescence emission (referred to as $\lambda$ em 4 by a dashed dotted line) to be used for time trace acquisitions (Fig. $2 B$ ) were superimposed
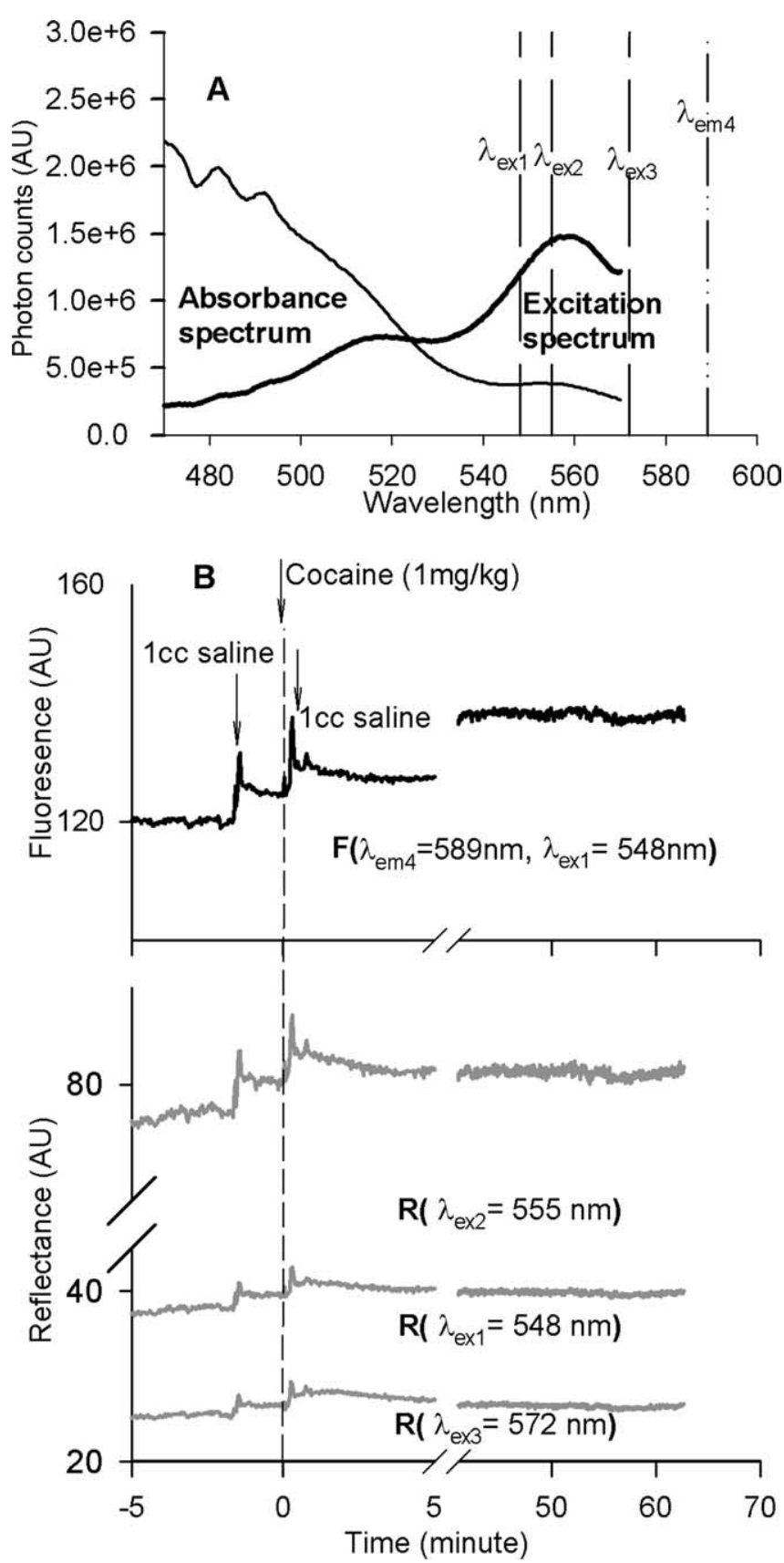

Figure 2. A, Hemoglobin absorbance spectrum and excitation spectra of calcium fluorescence indicator Rhod2 obtained from the surface of rat brain cortex. The vertical lines illustrate the center wavelengths of the excitation $(\lambda \operatorname{ex} 1, \lambda$ ex2, and $\lambda$ ex3) and fluorescence emission ( $\lambda$ em4). $\boldsymbol{B}$, Example of calcium-dependent fluorescence recording along with the reflectance of the excitations from the cortex of the brain simultaneously at those wavelengths in response to drug challenges. AU, Arbitrary units.

on the spectra. As shown in Figure $2 \mathrm{~A}$, these wavelengths were remote from the major absorption peaks of hemoglobin $(\sim 480-500 \mathrm{~nm})$, allowing a stronger fluorescence emission because of less attenuation by hemoglobin, thus providing a better signal-to-noise ratio for signal acquisition in vivo.

After the 60 min post-loading Rhod2 period, time traces were recorded for both fluorescence (emitted at $\lambda_{\mathrm{em} 4}=589 \mathrm{~nm}$ while excited at $\lambda_{\text {exl }}=548 \mathrm{~nm}$ ) and the diffuse reflectance at multiple wavelengths $\left(\lambda_{\mathrm{ex} 1}=548 \mathrm{~nm}, \lambda_{\mathrm{ex} 2}=555 \mathrm{~nm}\right.$, and $\left.\lambda_{\mathrm{ex} 3}=572 \mathrm{~nm}\right)$. The excitation and diffuse reflectance spectra were monitored periodically. Figure $2 B$ shows an example of the data acquisition of the fluorescence and the reflectance signals before, during, and after intravenous administration of vehicle 


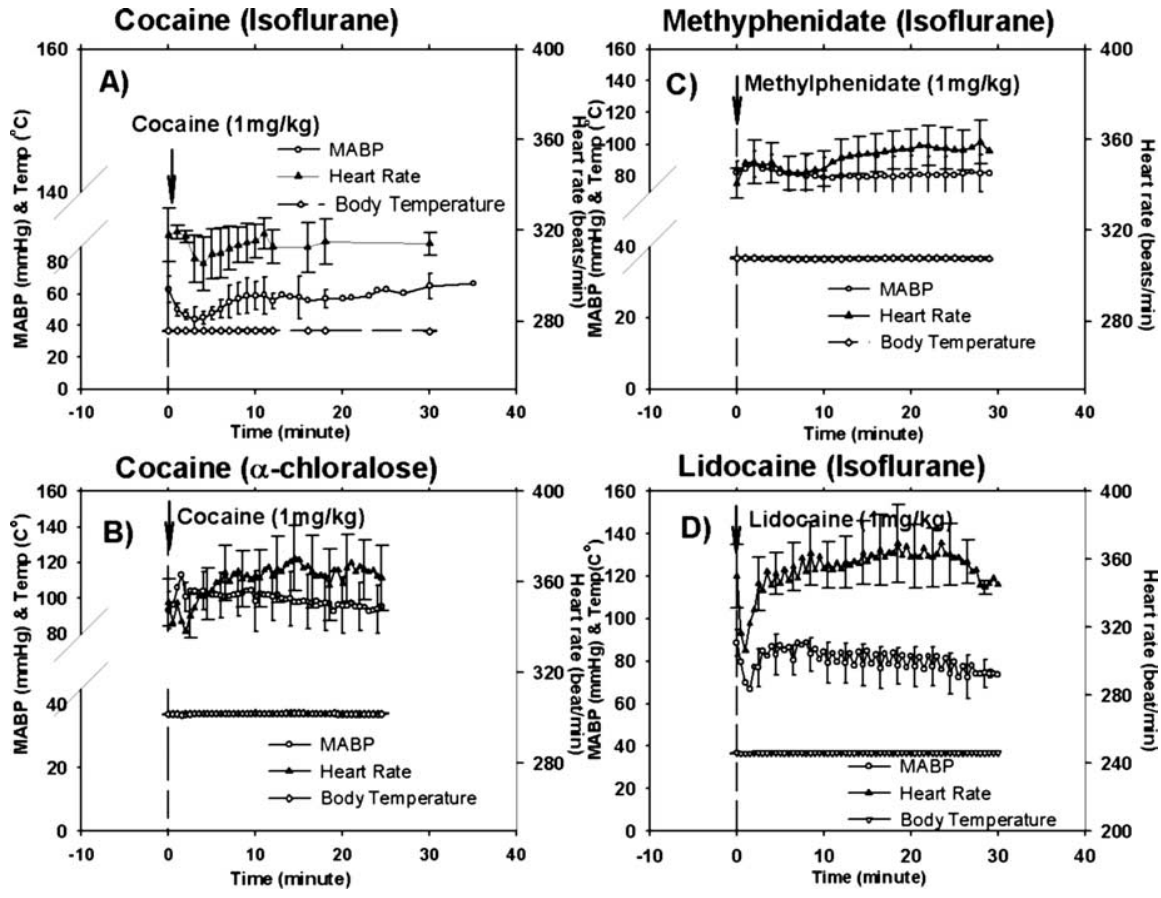

Figure 3. $M A B P$, heart rate (electrocardiogram), and body temperature (Temp) as a function of time in response to $1 \mathrm{mg} / \mathrm{kg}$ cocaine (isoflurane-anesthetized rats; $\boldsymbol{A}$ ), $1 \mathrm{mg} / \mathrm{kg}$ cocaine ( $\alpha$-chloralose-anesthetized rats; $\boldsymbol{B}), 1 \mathrm{mg} / \mathrm{kg}$ methylphenidate $(\boldsymbol{C})$, and $1 \mathrm{mg} / \mathrm{kg}$ lidocaine $(\boldsymbol{D})$. Data are presented as a mean \pm SEM.

and drugs (e.g., cocaine or methylphenidate). Recording was continued for $\sim 60$ min after drug administration. The two parameters, CBV and hemoglobin oxygenation $\left(\mathrm{S}_{\mathrm{t}} \mathrm{O}_{2}\right)$, can be separately distinguished from the reflectance obtained from the cortical surface at the wavelengths of 555 and $572 \mathrm{~nm}$. As has been described previously (Du et al., 2005), the summation and subtraction of the optical signal densities between these two wavelengths reflected the changes of the hemoglobin concentration (i.e., referring to the change in blood volume) and hemoglobin oxygenation, respectively, as follows:

$$
\begin{gathered}
\Delta O D^{\lambda \mathrm{ex} 2}+\Delta \mathrm{OD}^{\lambda \mathrm{ex} 3}=\left\{\left(\varepsilon_{H b}^{\lambda \mathrm{ex} 2}+\varepsilon_{H b}^{\lambda \mathrm{ex} 3}\right) \Delta[B V]\right\} B L \\
\Delta O D^{\lambda \mathrm{ex} 2}-\Delta \mathrm{OD}^{\lambda \mathrm{ex} 3}=\left\{\left(\varepsilon_{H b O}^{\lambda \operatorname{ex} 2}+\varepsilon_{H b}^{\lambda \operatorname{ex} 3}\right) \Delta[H b O]\right\} 2 B L,
\end{gathered}
$$

where $\triangle O D=O D_{\text {after }}-O D_{\text {before }}$ is the change in optical density before and after drug administration that was associated with the changes in hemoglobin concentrations; $\lambda_{\mathrm{ex} 2}=555 \mathrm{~nm}$ and $\lambda_{\mathrm{ex} 3}=572 \mathrm{~nm} ; \varepsilon_{\mathrm{Hb}}$ and $\varepsilon_{\mathrm{HbO}}$ are the extinction coefficients of the deoxygenated and oxygenated hemoglobin, which are constant; $B$ is a pathlength factor that accounts for changes in the photon pathlength caused by tissue scattering; and $L$ is the distance between where the light enters the tissue and where the detected light exits the tissue. $B$ and $L$ are assumed not to be changed during the experiments. Therefore, $\Delta[B V]$ and $\Delta[H b O]$ represent the changes in blood volume and oxygenated hemoglobin concentration induced by a given drug (e.g., cocaine, methylphenidate) or other hemodynamic manipulation (e.g., hypotension by exsanguination). Because both wavelengths of $548 \mathrm{~nm}$ (for Rhod2 excitation) and $589 \mathrm{~nm}$ (for Rhod2-Ca fluorescence emission) are the isosbestic wavelengths of tissue oxygenation as described previously (Du et al., 2001a,b, 2005), the influence of the variation in the oxygenation state of tissue on the fluorescence signal was eliminated. Furthermore, to minimize the interference of physiological changes (e.g., blood volume and possible cell swelling) on the Rhod2-calcium fluorescence, a ratio of fluorescent emission at 589 $\mathrm{nm}$ over reflected excitation at $548 \mathrm{~nm}$ was used as follows:

$$
\text { Rhod2 }-\mathrm{Ca}=F^{\lambda \mathrm{em} 4} / R^{\lambda \mathrm{ex} 1} .
$$

Thus, the ratio of $F^{\lambda \text { em4 }}$ over $R^{\lambda \text { ex } 1}$ represented intracellular calciumdependent fluorescence changes in response to drug challenges or exsan- guination. $F^{\lambda \mathrm{em} 4}$ and $R^{\lambda \text { ex } 1}$ represent Rhod2 emission at $589 \mathrm{~nm}\left(\lambda_{\mathrm{em} 4}\right)$ and reflectance at $548 \mathrm{~nm}\left(\lambda_{\text {ex } 1}\right)$, respectively.

The average signals of the diffuse reflectance and calcium-dependent Rhod2 fluorescence before $(\sim 10 \mathrm{~min})$ the vehicle, cocaine, methylphenidate, and lidocaine challenges or exsanguination insult were defined as baseline $(100 \%)$. All values were expressed as a percentage of baseline \pm SEM. Intragroup differences were analyzed with a paired Student's $t$ test, and intergroup differences were analyzed with ANOVA and a post hoc unpaired Student's $t$ test; $p<0.05$ was considered significant.

\section{Results}

Effects of cocaine on the MABP, heart rate, and body temperature

In the isoflurane-anesthetized rats (group $2 \mathrm{a})$, cocaine induced brief (3-4 $\mathrm{min}$ ) and transient mild hypotension; the MABP decreased from $\sim 62.8 \pm 8.5$ to $\sim 43.8 \pm 8.1$ $\mathrm{mmHg}(p<0.01)$ and also reduced heart rate $(318 \pm 2.4$ to $307 \pm 2.1$ beats $/ \mathrm{min}$ (bpm); $p<0.01$ ) (Fig. 3A). Both parameters returned to baseline levels by $8-10$ min after injection and remained within normal range for the rest of the recording period. No significant changes in body temperature were observed (Fig. $3 A$ ). In the $\alpha$-chloralose-anesthetized (group 2b) rats, cocaine increased MABP from $93.1 \pm 10.3 \mathrm{mmHg}$ (baseline) to $113.2 \pm 7.9 \mathrm{mmHg}$ within $2 \mathrm{~min}$ after injection $(p<0.01)$, and it rapidly $(<5-6 \mathrm{~min})$ recovered to $\sim 100 \mathrm{mmHg}$; the heart rate decreased slightly (not statistically significant; $p>0.05$ ) from $351 \pm 26.7$ to $338 \pm 29.7 \mathrm{bpm}$ within the initial $2 \mathrm{~min}$ of the injection and increased to $370.3 \pm 17.9 \mathrm{bpm}$ at $\sim 15 \mathrm{~min}$.

\section{Effects of cocaine on $\mathrm{CBV}$, oxygenation $\left(\mathrm{S}_{\mathrm{t}} \mathrm{O}_{2}\right)$, and} intracellular calcium ( $\mathrm{Rhod} 2-\mathrm{Ca}^{2+}$ )

Isoflurane-anesthetized rats

Cocaine induced transient decreases in CBV $(-4.2 \pm 1.2 \%$; $p<$ $0.05)$ and $\mathrm{S}_{\mathrm{t}} \mathrm{O}_{2}(-3.1 \pm 0.9 \% ; p<0.05) 3-4$ min after its injection (Fig. $4 A, B$ ). $\mathrm{CBV}$ and $\mathrm{S}_{\mathrm{t}} \mathrm{O}_{2}$ returned to baseline levels at 25 and $16 \mathrm{~min}$ after injection, respectively. In contrast, $\mathrm{CBV}$ and $\mathrm{S}_{\mathrm{t}} \mathrm{O}_{2}$ did not change in response to vehicle challenge in control rats (group 1) (Fig. 5A,B). A comparison of the temporal course for the effects of cocaine in CBV (Fig. $4 A$ ) with those in MABP (Fig. $3 A$ ) reveals that the decrease in $\mathrm{CBV}$ only coincides with the decrease in MABP over the first 3-4 min (e.g., MABP rapidly normalizes whereas CBV persists at a low level of $95 \%$ until $\sim 15$ min when it starts to recover).

Intracellular calcium, as measured by Rhod2-Ca fluorescence (Fig. 4C), was unchanged for $4-5 \mathrm{~min}$ after the cocaine challenge and gradually increased to a maximum of $\sim 10.3 \pm 1.3 \%$ at 42 min after injection (Table 2). The increase in fluorescence of Rhod2-Ca trended toward a slow recovery after $42 \mathrm{~min}$. In control rats (group 1), Rhod2-Ca fluorescence did not change over time in response to the vehicle challenge (Fig. $5 C$ ).

\section{$\alpha$-Chloralose-anesthetized rats}

In rats anesthetized with $\alpha$-chloralose (group 2b), cocaine elicited a slow and prolonged increase in $\mathrm{CBV}$ and $\mathrm{S}_{\mathrm{t}} \mathrm{O}_{2}$, which reached a peak of $\approx 2-3 \%$ above baseline levels at $\approx 25-30 \mathrm{~min}$ after the cocaine injection and gradually recovered over $1 \mathrm{~h}$ 

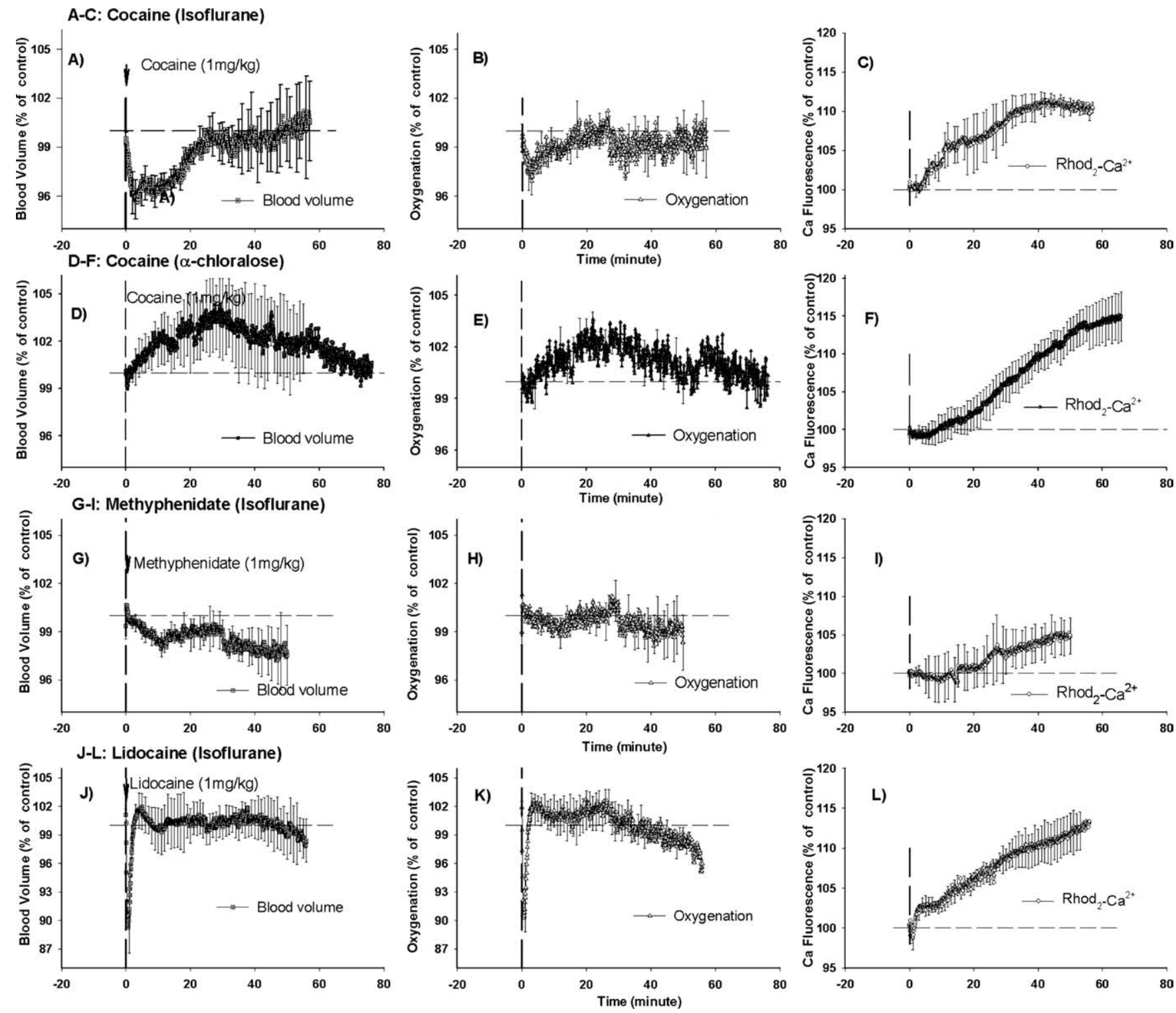

Figure 4. Optical diffusion and fluorescence recordings of $\left(B V\right.$, tissue oxygenation $\left(S_{t} O_{2}\right)$, and intracellular calcium $\left(\left[\mathrm{Ca}^{2+}\right]_{i}\right)$ from rat cortex after $1 \mathrm{mg} / \mathrm{kg}$ cocaine in isoflurane-anesthetized rats $(\boldsymbol{A}-\boldsymbol{C}), 1 \mathrm{mg} / \mathrm{kg}$ cocaine in $\alpha$-chloralose-anesthetized rats $(\boldsymbol{D}-\boldsymbol{F}), 1 \mathrm{mg} / \mathrm{kg}$ methylphenidate in isoflurane-anesthetized rats $(\mathbf{G}-\boldsymbol{I})$, and $1 \mathrm{mg} / \mathrm{kg}$ lidocaine in isoflurane-anesthetized rats $(J-\boldsymbol{L})$. The data are presented as relative changes from baseline (100\%). The vertical dashed lines in each graph represent the time of intravenous drug administration.

(Fig. $4 D, E$ ). Similarly to the isoflurane-anesthetized rats (group 2a) (Fig. $4 C$ ), $\left[\mathrm{Ca}^{2+}\right]_{\mathrm{i}}$ also increased excessively in the $\alpha$-chloralose-anesthetized rats after the cocaine challenge, although with a delay of $\approx 10 \mathrm{~min}$ (Fig. $4 \mathrm{~F}$, Table 2 ); the cocaineinduced $\left[\mathrm{Ca}^{2+}\right]_{\mathrm{i}}$ increase continued for $1 \mathrm{~h}$ and reached a plateau (Table 2).

\section{Cocaine, intracellular calcium, and changes in MABP}

To clarify the potential interdependency between the intracellular calcium changes and the systemic hypotension observed in the isoflurane rats, we examined the effect of transient hypotension induced by blood withdrawal on the optical recordings. First, the decrease in MABP induced by blood withdrawal was similar to that induced by cocaine in the isoflurane-anesthetized rats $(-36.4 \pm 5.8$ vs $-30.3 \pm 8.0 \%)$ (Fig. $5 D)$. Second, in response to the mild hypotension, $\mathrm{CBV}$ and $\mathrm{S}_{\mathrm{t}} \mathrm{O}_{2}$ decreased $-3.2 \pm 0.6$ and $-0.7 \pm 0.5 \%$, respectively (Fig. $5 D, E$ ). However, unlike cocaine, there was no significant Rhod2-Ca fluorescence increase (Fig. $5 F$ ) along with the decrease in the MABP (Fig. 5D). This experiment suggests that the intracellular calcium increase observed after the cocaine challenge in the isoflurane-anesthetized rats is neither attributable to the transient hypotensive episode nor to the changes in $\mathrm{CBV}$ or $\mathrm{S}_{\mathrm{t}} \mathrm{O}_{2}$. This conclusion is also supported by the consistent cocaine-induced $\left[\mathrm{Ca}^{2+}\right]_{i}$ increases in the $\alpha$-chloralose-anesthetized rats in which MABP is slightly elevated after systemic cocaine (Fig. 3B).

We also tested the effect of maintaining the MABP within normal range by administering phenylephrine at the time of cocaine exposure to circumvent the transient hypotension observed with cocaine in the isoflurane-anesthetized rats (Fig. 5G). Interestingly, despite normotension, the cocaine administration still resulted in a decrease in CBV (maximal change, $-8.2 \pm 1.3 \%$; $p<0.05$ ) and an increase in the Rhod2-Ca fluorescence (maxi- 

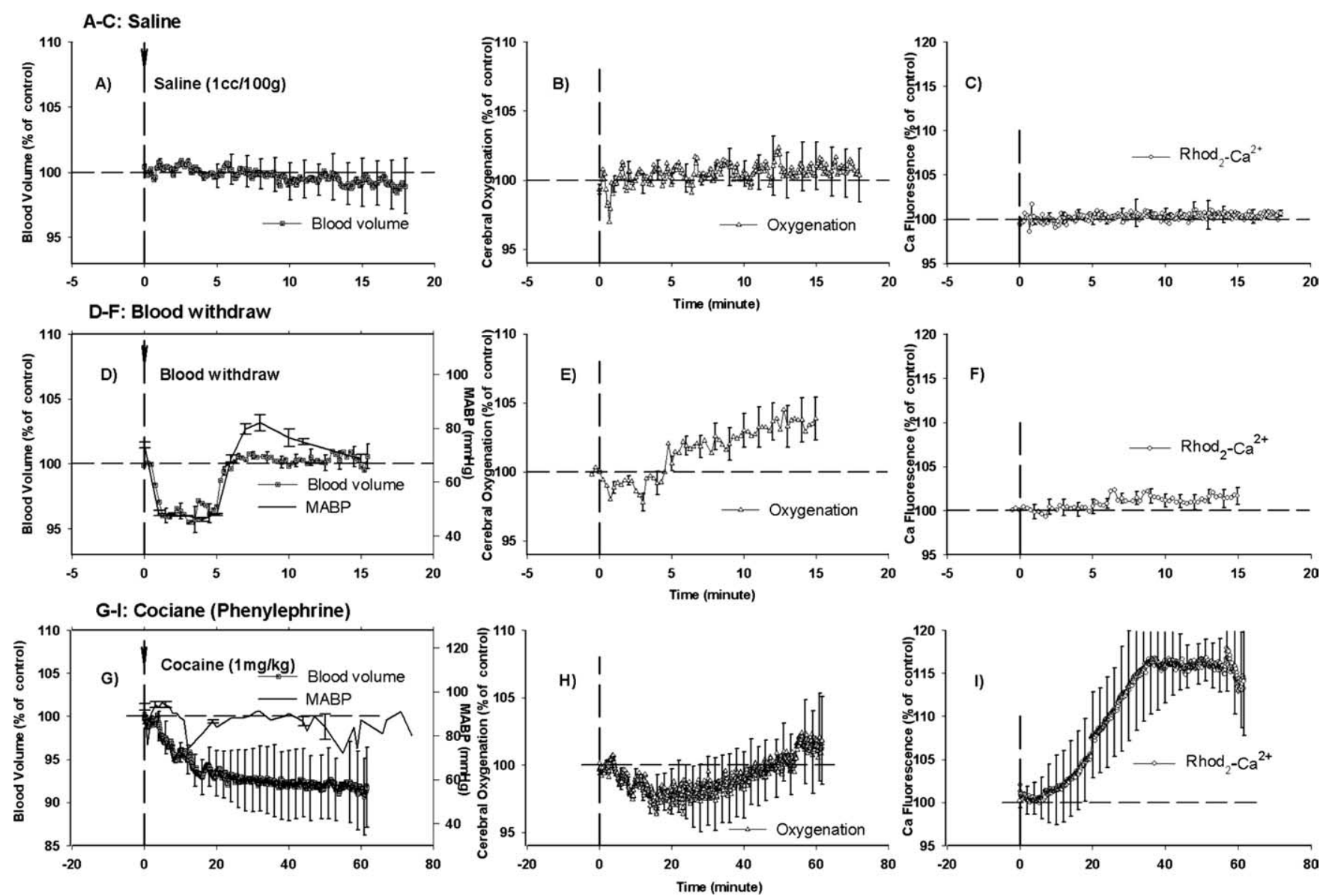

Figure 5. Optical diffusion and fluorescence recordings of $C B V$, tissue oxygenation $\left(S_{\mathrm{t}} \mathrm{O}_{2}\right)$, and intracellular calcium $\left(\left[\mathrm{Ca}^{2+}\right]_{\mathrm{i}}\right)$ from rat cortex after intravenous administration of vehicle/saline $(\boldsymbol{A}-\boldsymbol{C})$, blood exsanguination $(\boldsymbol{D}-\boldsymbol{F})$, and $1 \mathrm{mg} / \mathrm{kg}$ cocaine $(\mathbf{G}-\boldsymbol{I})$. In the experiment illustrated in $\mathbf{G}-\mathbf{I}$, the MABP was maintained normal with phenylephrine. The vertical lines represent the beginning of the injection or hemodynamic challenge.

Table 2. Effect of the drug administration on the intracellular calcium in the living rat brain

\begin{tabular}{llllll}
\hline & $\begin{array}{l}\text { Group 2a } \\
\text { (cocaine, isoflurane) }\end{array}$ & $\begin{array}{l}\text { Group 2b } \\
\text { (cocaine, } \alpha \text {-chloralose) }\end{array}$ & $\begin{array}{l}\text { Group 3 } \\
\text { (methylphenidate) }\end{array}$ & $\begin{array}{l}\text { Group 4 } \\
\text { (lidocaine) }\end{array}$ & $\begin{array}{l}\text { Group 6 } \\
\text { (cocaine, phenylephrine) }\end{array}$ \\
\hline $\begin{array}{l}\text { Time from cocaine injection to } \\
{\left[\mathrm{Ca}^{2+}\right]_{\mathrm{i}} \text { increase }(\mathrm{min})}\end{array}$ & $6.2 \pm 1.7$ & $8.8 \pm 0.7$ & $15.3 \pm 2.7^{*}$ & $2.2 \pm 0.2$ & $7.3 \pm 1.5$ \\
$\begin{array}{l}\text { Maximal }\left[\mathrm{Ca}^{2+}\right]_{\mathrm{i}} \text { increase } \\
(\% \text { from baseline) }\end{array}$ & $10.3 \pm 1.3$ & $14.7 \pm 2.3$ & $4.2 \pm 0.7^{*}$ & $13.3 \pm 2.4$ & $16.3 \pm 2.3$ \\
\hline
\end{tabular}

${ }^{*} p<0.05$, group 3 versus group $2 a$ and group 3 versus group 4.

mal change, $16.3 \pm 2.3 \% ; p<0.05$ ) (Fig. $5 G, I$ ). This result also suggests that the changes in intracellular calcium observed during a cocaine challenge are independent of changes in MABP, CBV, and $\mathrm{S}_{\mathrm{t}} \mathrm{O}_{2}$ changes.

\section{Physiological changes and cerebral responses induced} by methylphenidate

Methylphenidate induced increases in the heart rate that persisted for the 35 min recording period after its administration (Fig. 3C). In addition, it induced a transient increase in MABP. Peak percentage increases in heart rate and MABP corresponded to $4.0 \pm 1.6$ and $11.0 \pm 6.1 \%$, respectively (Fig. $3 C$ ). The body temperature was unaffected.

Methylphenidate caused a mild decrease in CBV $(-2.0 \pm$ $0.8 \%$ at $11 \mathrm{~min}$ ) but no significant change in $\mathrm{S}_{\mathrm{t}} \mathrm{O}_{2}(-1.9 \pm 1.2 \%)$ (Fig. 4G,H). The methylphenidate-induced CBV decrease was lower than that induced by cocaine in the isoflurane-anesthetized rats (group 2a) and persisted for $>40 \mathrm{~min}(p<0.02$ ). Importantly, the Rhod2-Ca fluorescence was unchanged for $\sim 15 \mathrm{~min}$, increased slightly, and reached a peak of $4.2 \pm 0.7 \%$ (Fig. $4 I$ ), which was significantly lower $(p<0.003)$ than for cocaine (i.e., $10.3 \pm 1.3 \%$ as shown in Fig. $4 C$ and Table 2 ).

Physiological changes and cerebral and $\left[\mathrm{Ca}^{2+}\right]_{\mathrm{i}}$ responses induced by lidocaine

Intravenous lidocaine briefly (2-3 min) decreased the MABP from $88.6 \pm 6.1$ to $66.9 \pm 11.5 \mathrm{mmHg}$ and the heart rate from $349.8 \pm 18.5$ to $306.2 \pm 18.6 \mathrm{bpm}$ within $\approx 1 \mathrm{~min}$ (Fig. $3 D$ ). In parallel, $\mathrm{CBV}$ and $\mathrm{S}_{\mathrm{t}} \mathrm{O}_{2}$ briefly and transiently decreased $\approx 10 \%$ (CBV, $10.7 \pm 4.3 \% ; \mathrm{S}_{\mathrm{t}} \mathrm{O}_{2}, 9.7 \pm 4.0 \%$ ) (Fig. 4, compare $J, K$ ). Both parameters recovered with a minor overshoot within $3 \mathrm{~min}$. The fluorescence-dependent Ca signal started to increase within 
$2 \mathrm{~min}$ and rose significantly to a maximum of $13.3 \pm 2.4 \%$ at $\sim 50$ min after the lidocaine injection (Fig. $4 L$ ), which was similar to the $\left[\mathrm{Ca}^{2+}\right]_{\mathrm{i}}$ increases observed with cocaine $(p>0.05)$.

\section{Discussion}

This study provides evidence for the first time in vivo that acute cocaine at a dose used by cocaine abusers for recreational purposes significantly increases the intracellular calcium concentration $\left(\left[\mathrm{Ca}^{2+}\right]_{\mathrm{i}}\right)$ in the rodent brain and that these effects are independent of changes in peripheral and central hemodynamics. It also shows that methylphenidate at a dose that is approximately double in potency to that used for cocaine in blocking dopamine and norepinephrine transporters (Han and $\mathrm{Gu}, 2006$ ) did not increase $\left[\mathrm{Ca}^{2+}\right]_{\mathrm{i}}$, suggesting that cocaine-induced increases in $\left[\mathrm{Ca}^{2+}\right]_{\mathrm{i}}$ are not caused by its dopaminergic or its noradrenergic actions. Finally, it documents that intravenous lidocaine induced increases in intracellular $\left[\mathrm{Ca}^{2+}\right]_{\mathrm{i}}$ similar to those observed with cocaine, suggesting that the mechanism whereby cocaine evokes $\left[\mathrm{Ca}^{2+}\right]_{\mathrm{i}}$ increases is via its local anesthetic effects and not by its catecholaminergic actions.

\section{The effects of cocaine on intracellular calcium concentration $\left(\left[\mathrm{Ca}^{2+}\right]_{\mathbf{i}}\right)$}

Using a novel optical diffusion fluorescence device, we demonstrated for the first time in vivo that an acute cocaine challenge induced increases in $\left[\mathrm{Ca}^{2+}\right]_{\mathrm{i}}$ in the brain. We examined the effect of cocaine on the $\left[\mathrm{Ca}^{2+}\right]_{i}$ response in both isoflurane- and $\alpha$-chloralose-anesthetized animals because of the cocaineinduced differences in the hemodynamic profiles with the two anesthetic regimens (see below). As described, in the isofluraneanesthetized animals, the $\left[\mathrm{Ca}^{2+}\right]_{\mathrm{i}}$ started to increase $\approx 6 \mathrm{~min}$ after cocaine and gradually increased to $\approx 10-11 \%$ above the baseline at $\sim 40 \mathrm{~min}$. In the $\alpha$-chloralose-anesthetized animals, cocaine induced an $\approx 14 \%\left[\mathrm{Ca}^{2+}\right]_{\mathrm{i}}$ increase although it occurred slightly later $(\approx 9 \mathrm{~min})$. It is noteworthy that the cocaine-induced $\left[\mathrm{Ca}^{2+}\right]_{\mathrm{i}}$ increase, regardless of anesthetic, was quantitatively larger than that observed in transient ( $5 \mathrm{~min}$ ) global ischemia in which it only increases $\sim 8.5 \pm 1.7 \%$ compared with baseline ( $\mathrm{Du}$ et al., 2005). In transient cerebral ischemia, there is a clear pathophysiological link between ischemia, calcium transients, and ensuing selective neuronal death (Benveniste et al., 1988). For example, selective neuronal necrosis that occurs in the brain after short-term (5-15 min) transient ischemia is associated with extracellular calcium decreases (Benveniste et al., 1988) or intracellular calcium increases (Silver and Erecinska, 1990). Furthermore, inhibition of calcium transients prevents neuronal death after a $10 \mathrm{~min}$ ischemic insult (Benveniste et al., 1988). However, the cocaine-induced $\left[\mathrm{Ca}^{2+}\right]_{\mathrm{i}}$ increases observed in this study occur under non-ischemic conditions [ischemia defined here as a CBF of $<20 \mathrm{cc} / 100 \mathrm{~g} / \mathrm{min}$ (Astrup et al., 1977; Symon et al., 1977)] and may explain why direct cell damage has not been documented after acute cocaine administration.

To clarify whether the cocaine-induced increases in $\left[\mathrm{Ca}^{2+}\right]_{\mathrm{i}}$ were dependent on hemodynamic changes (i.e., MABP), we measured Rhod2-Ca fluorescence changes under different conditions, (1) during two different anesthesia regimens and (2) in response to exsanguinations, and we also measured $\mathrm{CBV}, \mathrm{S}_{\mathrm{t}} \mathrm{O}_{2}$, and Rhod2-Ca changes while we maintained stable blood pressure during the cocaine administration with phenylephrine in isoflurane-anesthetized animals in which cocaine induced brief, transient hypotension. The fact that there was no significant change in Rhod2-Ca fluorescence in response to the transient decrease in blood pressure (Fig. $5 F$ ) suggests that the Rhod2-Ca fluorescence increase was not caused by the peripheral hemodynamic effects of cocaine. Moreover, with stable blood pressures in both $\alpha$-chloralose-anesthetized animals (Fig. $4 F$ ) and in isoflurane-anesthetized animals in which MABP was maintained normal with phenylephrine (Fig. 5G), cocaine still induced an increase in Rhod2-Ca fluorescence, corroborating the fact that the cocaine-induced $\left[\mathrm{Ca}^{2+}\right]_{\mathrm{i}}$ increase occurs independent of changes in peripheral hemodynamics.

An interesting finding from our study is that the increases in $\left[\mathrm{Ca}^{2+}\right]_{\mathrm{i}}$ persisted for $>60 \mathrm{~min}$ after the cocaine injection, which is a time when the concentration of cocaine in plasma is negligible (Carmona et al., 2005). Indeed, the half-life for the concentration of cocaine in plasma in the rat is $\sim 26 \mathrm{~min}$ (Carmona et al., 2005), which suggests that the increases in $\left[\mathrm{Ca}^{2+}\right]_{\mathrm{i}}$ are attributable to a cocaine metabolite that is detectable a long time after cocaine in plasma is no longer present (Burke and Ravi, 1990; Burke et al., 1990), rather than to cocaine itself. Interestingly, the blockade of cocaine of norepinephrine transporters in the primate heart persists hours after its administration (Fowler et al., 1994) even when the half-life of cocaine in myocardium is $\sim 10 \mathrm{~min}$ (Volkow et al., 1996).

In the adult organism, cocaine is metabolized mostly through hydrolysis and enzymatically into its major metabolites, ecgonine methyl ester, benzoylecgonine, and to $N$-demethylation by cytochrome P-450 enzymes to produce norcocaine (Inaba, 1989). In humans, the half-life of benzoylecgonine is known to be longer than in rats (Dempsey et al., 1999) and can be detected in the urine for $>96$ h (Hamilton et al., 1977). Like cocaine, benzoylecgonine passes the blood-brain barrier (Spiehler and Reed, 1985), and both compounds can constrict cerebral arteries (Madden and Powers, 1990). In fact, benzoylecgonine constricts cerebral arteries more than cocaine (Madden and Powers, 1990). Thus, given the pharmacokinetic profiles, a potential cocaine metabolite candidate eliciting the $\left[\mathrm{Ca}^{2+}\right]_{\mathrm{i}}$ increases observed in this study could be benzoylecgonine. Alternatively, we cannot rule out the possibility that cocaine may induce conformational changes in ion channels that persist after the drug is no longer present in the tissue. Future studies will clarify this issue.

\section{The effects of methylphenidate on $\left[\mathrm{Ca}^{2+}\right]_{\mathrm{i}}$}

Unlike cocaine, acute methylphenidate did not elicit a large increase in Rhod2-Ca-dependent fluorescence (methylphenidate, $4.2 \pm 0.7 \%$; cocaine, $10.3 \pm 1.3 \%$ ), and it occurred significantly later (15 vs $6 \mathrm{~min}$ ) (Table 2). Methylphenidate, like cocaine, is a dopamine transporter and a norepinephrine transporter inhibitor but differs from cocaine in that it is devoid of local anesthetic actions and does not bind to the serotonin transporter (Ritz et al., 1987). Thus, the differences between cocaine and methylphenidate in the induction of increases $\left[\mathrm{Ca}^{2+}\right]_{\mathrm{i}}$ could be attributable to either the differences in their serotonergic effects or their local anesthetic properties. The fact that lidocaine, which is devoid of catecholamienrgic effects, has similar effects to those of cocaine in increasing $\left[\mathrm{Ca}^{2+}\right]_{\mathrm{i}}$ suggests that it is the local anesthetic and not the serotonergic effects of cocaine that underlie its $\left[\mathrm{Ca}^{2+}\right]_{i}$ increases (see below).

\section{The effects of lidocaine on $\left[\mathrm{Ca}^{2+}\right]_{\mathrm{i}}$}

Intravenous lidocaine in a clinical relevant dose elicited similar $(10-13 \%)\left[\mathrm{Ca}^{2+}\right]_{\mathrm{i}}$ increases to that of cocaine, although they occurred more rapidly ( 2.2 vs $6.2 \mathrm{~min}$ ), providing strong evidence that cocaine elicits $\left[\mathrm{Ca}^{2+}\right]_{\mathrm{i}}$ increases via its local anesthetic action. It has been known for decades that local anesthetics have the potential to permanently damage the spinal cord (Ferguson 
and Watkins, 1937; Macdonald and Watkins, 1937); however, the mechanism behind their neurotoxic action is still unresolved. Our study demonstrates for the first time in vivo that a local anesthetic (lidocaine) causes $\left[\mathrm{Ca}^{2+}\right]_{\mathrm{i}}$ increases in the brain that may explain its potential neurotoxicity, especially when local anesthetics are combined with vasoactive agents such as epinephrine, which is often administered in conjunction with the local anesthetic when used clinically. Interestingly, Gold et al. (1998) have demonstrated in vitro that lidocaine in cultured dorsal root ganglion cells also causes increases in the free intracellular concentration of calcium (see also Kirihara et al., 2003; Sakura et al., 2005) and have suggested that this is involved in its toxic effects. Our in vivo data strongly corroborates the data of Gold et al. (1998), and future studies with our new optical approach will confirm whether the lidocaine-induced $\left[\mathrm{Ca}^{2+}\right]_{\mathrm{i}}$ increases in the brain are also observed in the peripheral nervous system.

\section{The effects of cocaine on $\mathrm{CBV}$ and $\mathrm{S}_{\mathrm{t}} \mathrm{O}_{2}$}

In the isoflurane-anesthetized animals, the initial cocaineinduced decrease in CBV occurred in close temporal correspondence to the decrease in blood pressure (Figs. 3A, 4A). However, the decrease in CBV persisted after the MABP had recovered. This mismatch between CBV and MABP (i.e., after $8 \mathrm{~min}$ ) was not confirmed in animals anesthetized with $\alpha$-chloralose in which cocaine induced an increase in both $\mathrm{CBV}$ and $\mathrm{S}_{\mathrm{t}} \mathrm{O}_{2}$, whereas MABP was stable and slightly elevated. Therefore, the $\mathrm{CBV}$ and $\mathrm{S}_{\mathrm{t}} \mathrm{O}_{2}$ response to cocaine is dependent on the anesthetic used. The conflicting hemodynamic responses to cocaine with different anesthetic regimens could explain reported discrepancies in the literature using MRI to investigate the effects of systemic cocaine. For example, using $0.7 \%$ halothane, $1 \mathrm{mg} / \mathrm{kg}$ cocaine was found to elicit widespread increases in regional $\mathrm{CBV}$ using contrast and functional MRI (fMRI) (Marota et al., 2000). In another study, urethane was used as an anesthetic, and cocaine was found to cause widespread and dosedepended early decreases and later increases in the blood oxygenation level-dependent (BOLD) fMRI signal with intravenous cocaine challenges in the rat brain (Luo et al., 2003). Recently, isoflurane-anesthetized rats were used, and intravenous cocaine $(1 \mathrm{mg} / \mathrm{kg})$ was found to elicit a negative BOLD fMRI signal on the cortical surface (Schmidt et al., 2006), which is especially relevant for our study because our optical probe only records changes in the cortical surface (1-2 $\mathrm{mm}$ ) (Du et al., 2005).

In humans, abusing intravenous cocaine has been shown to reduce regional glucose metabolism in neocortical areas, basal ganglia, and the hippocampus (London et al., 1990) and to reduce global and regional CBF (Johnson et al., 2005). Studies on the effects of acute cocaine on the BOLD responses of the human brain (cocaine abusers) have been inconsistent with reports of increases in limbic and cortical regions (Breiter et al., 1997) as well as decreases (Risinger et al., 2005). Our data would suggest that the fMRI signal is negative in the isoflurane-anesthetized rats and positive in the $\alpha$-chloralose-anesthetized rats. However, all of our data are acquired in cocaine-naive rats and cannot be directly compared with the human data acquired in subjects regularly abusing cocaine. It is, however, important to emphasize that the $\left[\mathrm{Ca}^{2+}\right]_{\mathrm{i}}$ increases in response to cocaine occur regardless of the anesthetic and hemodynamic response and we are hypothesizing therefore that this would also occur in the human brain contributing to the neurotoxic potential of cocaine.

\section{Optical method used}

This study also demonstrates the feasibility of using optical imaging to simultaneously assess $\mathrm{CBV}, \mathrm{S}_{\mathrm{t}} \mathrm{O}_{2}$, and $\left[\mathrm{Ca}^{2+}\right]_{\mathrm{i}}$ in the rodent brain. Moreover, the optical fluorescence technique used to measure $\left[\mathrm{Ca}^{2+}\right]_{\mathrm{i}}$ was not affected by the vascular changes in $\mathrm{CBV}$ and $\mathrm{S}_{\mathrm{t}} \mathrm{O}_{2}$ attributable to cocaine. Considering the strong optical effects of changing CBV and $\mathrm{S}_{\mathrm{t}} \mathrm{O}_{2}$ in the previous ischemia experiments (Du et al., 2005), it is clear that the strategy to use appropriate wavelengths to measure Rhod2-Ca fluorescence enables reliable measurements of changes (Del Nido et al., 1998; Du et al., 2001a,b).

\section{Clinical significance}

It is well recognized that cocaine abuse is associated with neurological deficits that can be mild and transient such as facial paralysis to severe and irreversible such as permanent tetraplegia (Spivey and Euerle, 1990). In as much as increases in $\left[\mathrm{Ca}^{2+}\right]_{\mathrm{i}}$ are associated with cell death (Schanne et al., 1979), cocaine-induced increases in $\left[\mathrm{Ca}^{2+}\right]_{\mathrm{i}}$ are likely to be clinically relevant, particularly when considering that they occur in parallel to cocaineinduced decreases in MABP, blood volume, tissue oxygenation, and CBF. The increases in $\left[\mathrm{Ca}^{2+}\right]_{\mathrm{i}}$ would make the tissue more vulnerable to ischemia secondary to decreases in CBF that would otherwise not induce ischemia and/or cell damage. Cocaineinduced increases in $\left[\mathrm{Ca}^{2+}\right]_{\mathrm{i}}$ in brain are also likely to contribute to the pathogenesis of seizure activity, which is one of the most frequent complications associated with cocaine overdoses (Kaye and Darke, 2004). Indeed, studies have shown that intracellular calcium overload is a hallmark pathological finding after seizure activity (Meldrum, 1986a,b).

In summary, we show that acute cocaine at a dose used by cocaine abusers for recreational purposes induced large increases in $\left[\mathrm{Ca}^{2+}\right]_{\mathrm{i}}$ in the cortex of the rat brain that are independent of its decreases in $\mathrm{CBV}$ and in tissue oxygenation. We also document that the mechanism behind the cocaine-induced $\left[\mathrm{Ca}^{2+}\right]_{i}$ increases are related to the local anesthetic actions of cocaine and not its sympathomimetic effects. These findings are clinically relevant because they suggest that the neurotoxic effects of cocaine are directly related to $\left[\mathrm{Ca}^{2+}\right]_{i}$ and support the use of calcium channel blockers as a strategy to minimize brain damage after cocaine abuse.

\section{References}

Astrup J, Symon L, Branston NM, Lassen NA (1977) Cortical evoked potential and extracellular $\mathrm{K}+$ and $\mathrm{H}+$ at critical levels of brain ischemia. Stroke 8:51-57.

Bartzokis G, Beckson M, Lu PH, Edwards N, Rapoport R, Bridge P, Mintz J (2004) Cortical gray matter volumes are associated with subjective responses to cocaine infusion. Am J Addict 13:64-73.

Benveniste H, Jorgensen MB, Diemer NH, Hansen AJ (1988) Calcium accumulation by glutamate receptor activation is involved in hippocampal cell damage after ischemia. Acta Neurol Scand 78:529-536.

Berwick J, Devonshire IM, Martindale AJ, Johnston D, Zheng Y, Kennerley AJ, Overton PG, Mayhew JE (2005) Cocaine administration produces a protracted decoupling of neural and haemodynamic responses to intense sensory stimuli. Neuroscience 132:361-374.

Bolouri MR, Small GA (2004) Neuroimaging of hypoxia and cocaineinduced hippocampal stroke. J Neuroimaging 14:290-291.

Breiter HC, Rosen BR (1999) Functional magnetic resonance imaging of brain reward circuitry in the human. Ann NY Acad Sci 877:523-547.

Breiter HC, Gollub RL, Weisskoff RM, Kennedy DN, Makris N, Berke JD, Goodman JM, Kantor HL, Gastfriend DR, Riorden JP, Mathew RT, Rosen BR, Hyman SE (1997) Acute effects of cocaine on human brain activity and emotion. Neuron 19:591-611.

Burke WM, Ravi NV (1990) Urinary excretion of cocaine. Ann Intern Med 112:548-549. 
Burke WM, Ravi NV, Dhopesh V, Vandegrift B, Maany I (1990) Prolonged presence of metabolite in urine after compulsive cocaine use. J Clin Psychiatry 51:145-148.

Buttner A, Mall G, Penning R, Sachs H (2003) The neuropathology of cocaine abuse. Leg Med (Tokyo), Mar 5 Suppl 1:S240-S242.

Carmona GN, Schindler CW, Greig NH, Holloway HW, Jufer RA, Cone EJ, Gorelick DA (2005) Intravenous butyrylcholinesterase administration and plasma and brain levels of cocaine and metabolites in rats. Eur J Pharmacol 517:186-190.

Chance B, Leigh JS, Miyake H, Smith DS, Nioka S, Greenfeld R, Finander M, Kaufmann K, Levy W, Young M, Cohen P, Yoshioka H, Boretsky R (1988) Comparison of time-resolved and -unresolved measurements of deoxyhemoglobin in brain. Proc Natl Acad Sci USA 85:4971-4975.

Cope M, Delpy DT (1988) System for long-term measurement of cerebral blood and tissue oxygenation on newborn infants by near infra-red transillumination. Med Biol Eng Comput 26:289-294.

De R, Uppal HS, Shehab ZP, Hilger AW, Wilson PS, Courteney-Harris R (2003) Current practices of cocaine administration by UK otorhinolaryngologists. J Laryngol Otol 117:109-112.

Del Nido PJ, Glynn P, Buenaventura P, Salama G, Koretsky AP (1998) Fluorescence measurement of calcium transients in perfused rabbit heart using rhod 2. Am J Physiol 274:H728-H741.

Dempsey D, Jacob III P, Partridge JC, Jones RT, Panganiban K, Rowbotham MC (1999) Cocaine metabolite kinetics in the newborn. J Anal Toxicol 23:24-28.

Devonshire IM, Berwick J, Jones M, Martindale J, Johnston D, Overton PG, Mayhew JE (2004) Haemodynamic responses to sensory stimulation are enhanced following acute cocaine administration. NeuroImage 22:1744-1753.

Du C, MacGowan GA, Farkas DL, Koretsky AP (2001a) Calcium measurements in perfused mouse heart: quantitating fluorescence and absorbance of Rhod-2 by application of photon migration theory. Biophys J 80:549-561.

Du C, MacGowan GA, Farkas DL, Koretsky AP (2001b) Calibration of the calcium dissociation constant of Rhod(2)in the perfused mouse heart using manganese quenching. Cell Calcium 29:217-227.

Du C, Koretsky AP, Izrailtyan I, Benveniste H (2005) Simultaneous detection of blood volume, oxygenation, and intracellular calcium changes during cerebral ischemia and reperfusion in vivo using diffuse reflectance and fluorescence. J Cereb Blood Flow Metab 25:1078-1092.

Ferguson FR, Watkins KH (1937) Paralysis of the bladder and associated neurological sequelae of spinal anaesthesia (cauda equina syndrome). Br J Surg 25:735-752.

Fowler JS, Ding YS, Volkow ND, Martin T, MacGregor RR, Dewey S, King P, Pappas N, Alexoff D, Shea C (1994) PET studies of cocaine inhibition of myocardial norepinephrine uptake. Synapse 16:312-317.

Gissen AJ, Covino BG, Gregus J (1980) Differential sensitivities of mammalian nerve fibers to local anesthetic agents. Anesthesiology 53:467-474.

Gold MS, Reichling DB, Hampl KF, Drasner K, Levine JD (1998) Lidocaine toxicity in primary afferent neurons from the rat. J Pharmacol Exp Ther 285:413-421.

Grynkiewicz G, Poenie M, Tsien RY (1985) A new generation of Ca2+ indicators with greatly improved fluorescence properties. J Biol Chem 260:3440-3450.

Hamilton HE, Wallace JE, Shimek Jr EL, Land P, Harris SC, Christenson JG (1977) Cocaine and benzoylecgonine excretion in humans. J Forensic Sci 22:697-707.

Han DD, Gu HH (2006) Comparison of the monoamine transporters from human and mouse in their sensitivities to psychostimulant drugs. BMC Pharmacol 6:6.

Helmchen F, Waters J (2002) Ca2 + imaging in the mammalian brain in vivo. Eur J Pharmacol 447:119-129.

Inaba T (1989) Cocaine: pharmacokinetics and biotransformation in man. Can J Physiol Pharmacol 67:1154-1157.

Jobsis FF (1977) Non-invasive, infra-red monitoring of cerebral O2 sufficiency, blood volume, $\mathrm{HbO} 2-\mathrm{Hb}$ shifts and blood flow. Acta Neurol Scand Suppl 64:452-453.

Johnson BA, Devous MD Sr, Ruiz P, Ait-Daoud N (2001) Treatment advances for cocaine-induced ischemic stroke: focus on dihydropyridineclass calcium channel antagonists. Am J Psychiatry 158:1191.

Johnson BA, Dawes MA, Roache JD, Wells LT, Ait-Daoud N, Mauldin JB, Wang Y, Lancaster JL, Fox PT (2005) Acute intravenous low- and high- dose cocaine reduces quantitative global and regional cerebral blood flow in recently abstinent subjects with cocaine use disorder. J Cereb Blood Flow Metab 25:928-936.

Kaye S, Darke S (2004) Non-fatal cocaine overdose among injecting and non-injecting cocaine users in Sydney. Addiction 99:1315-1322.

Kirihara Y, Saito Y, Sakura S, Hashimoto K, Kishimoto T, Yasui Y (2003) Comparative neurotoxicity of intrathecal and epidural lidocaine in rats. Anesthesiology 99:961-968.

Kudo Y, Akita K, Nakamura T, Ogura A, Makino T, Tamagawa A, Ozaki K, Miyakawa A (1992) A single optical fiber fluorometric device for measurement of intracellular $\mathrm{Ca} 2+$ concentration: its application to hippocampal neurons in vitro and in vivo. Neuroscience 50:619-625.

Lee JH, Telang FW, Springer Jr CS, Volkow ND (2003) Abnormal brain activation to visual stimulation in cocaine abusers. Life Sci 73:1953-1961.

London ED, Cascella NG, Wong DF, Phillips RL, Dannals RF, Links JM, Herning R, Grayson R, Jaffe JH, Wagner Jr HN (1990) Cocaine-induced reduction of glucose utilization in human brain. A study using positron emission tomography and [fluorine 18]-fluorodeoxyglucose. Arch Gen Psychiatry 47:567-574.

Luo F, Wu G, Li Z, Li SJ (2003) Characterization of effects of mean arterial blood pressure induced by cocaine and cocaine methiodide on BOLD signals in rat brain. Magn Reson Med 49:264-270.

Macdonald AD, Watkins KH (1937) An experimental investigation into the cause of paralysis following spinal anaesthesia. Br J Surg 25:879-883.

Madden JA, Powers RH (1990) Effect of cocaine and cocaine metabolites on cerebral arteries in vitro. Life Sci 47:1109-1114.

Mandeville JB, Jenkins BG, Kosofsky BE, Moskowitz MA, Rosen BR, Marota JJ (2001) Regional sensitivity and coupling of BOLD and CBV changes during stimulation of rat brain. Magn Reson Med 45:443-447.

Marota JJ, Mandeville JB, Weisskoff RM, Moskowitz MA, Rosen BR, Kosofsky BE (2000) Cocaine activation discriminates dopaminergic projections by temporal response: an fMRI study in rat. NeuroImage 11:13-23.

Martin DH, DiCarlo RP (1994) Recent changes in the epidemiology of genital ulcer disease in the United States. The crack cocaine connection. Sex Transm Dis 21[2 Suppl]:S76-S80.

Meldrum BS (1986a) Neuropathological consequences of chemically and electrically induced seizures. Ann NY Acad Sci 462:186-193.

Meldrum BS (1986b) Cell damage in epilepsy and the role of calcium in cytotoxicity. Adv Neurol 44:849-855.

Minta A, Kao JP, Tsien RY (1989) Fluorescent indicators for cytosolic calcium based on rhodamine and fluorescein chromophores. J Biol Chem 264:8171-8178.

Nasif FJ, Hu XT, White FJ (2005) Repeated cocaine administration increases voltage-sensitive calcium currents in response to membrane depolarization in medial prefrontal cortex pyramidal neurons. J Neurosci 25:3674-3679.

Pearlson GD, Jeffery PJ, Harris GJ, Ross CA, Fischman MW, Camargo EE (1993) Correlation of acute cocaine-induced changes in local cerebral blood flow with subjective effects. Am J Psychiatry 150:495-497.

Risinger RC, Salmeron BJ, Ross TJ, Amen SL, Sanfilipo M, Hoffmann RG, Bloom AS, Garavan H, Stein EA (2005) Neural correlates of high and craving during cocaine self-administration using BOLD fMRI. NeuroImage 26:1097-1108.

Ritz MC, Lamb RJ, Goldberg SR, Kuhar MJ (1987) Cocaine receptors on dopamine transporters are related to self-administration of cocaine. Science 237:1219-1223.

Sakura S, Kirihara Y, Muguruma T, Kishimoto T, Saito Y (2005) The comparative neurotoxicity of intrathecal lidocaine and bupivacaine in rats. Anesth Analg 101:541-547.

Schanne FA, Kane AB, Young EE, Farber JL (1979) Calcium dependence of toxic cell death: a final common pathway. Science 206:700-702.

Schmidt KF, Febo M, Shen Q, Luo F, Sicard KM, Ferris CF, Stein EA, Duong TQ (2006) Hemodynamic and metabolic changes induced by cocaine in anesthetized rat observed with multimodal functional MRI. Psychopharmacology (Berl) 185:479-486.

Silver IA, Erecinska M (1990) Intracellular and extracellular changes of $[\mathrm{Ca} 2+]$ in hypoxia and ischemia in rat brain in vivo. J Gen Physiol 95:837-866.

Spiehler VR, Reed D (1985) Brain concentrations of cocaine and benzoylecgonine in fatal cases. J Forensic Sci 30:1003-1011. 
Spivey WH, Euerle B (1990) Neurologic complications of cocaine abuse. Ann Emerg Med 19:1422-1428.

Stankovic MR, Fujii A, Maulik D, Kirby D, Stubblefield PG (1998) Optical brain monitoring of the cerebrovascular effects induced by acute cocaine exposure in neonatal pigs. J Matern Fetal Investig 8:108-112.

Symon L, Lassen NA, Astrup J, Branston NM (1977) Thresholds of ischaemia in brain cortex. Adv Exp Med Biol 94:775-782.

Takahashi MP, Sugiyama M, Tsumoto T (1993) Contribution of NMDA receptors to tetanus-induced increase in postsynaptic $\mathrm{Ca} 2+$ in visual cortex of young rats. Neurosci Res 17:229-239.

Trantham-Davidson H, Lavin A (2004) Acute cocaine administration depresses cortical activity. Neuropsychopharmacology 29:2046-2051.

Uchimura N, North RA (1990) Actions of cocaine on rat nucleus accumbens neurones in vitro. Br J Pharmacol 99:736-740.

Volkow ND, Mullani N, Gould KL, Adler S, Krajewski K (1988) Cerebral blood flow in chronic cocaine users: a study with positron emission tomography. Br J Psychiatry 152:641-648.

Volkow ND, Fowler JS, Wolf AP, Wang GJ, Logan J, MacGregor R, Dewey SL, Schlyer D, Hitzemann R (1992) Distribution and kinetics of carbon-11-cocaine in the human body measured with PET. J Nucl Med 33:521-525.
Volkow ND, Ding YS, Fowler JS, Wang GJ (1996) Cocaine addiction: hypothesis derived from imaging studies with PET. J Addict Dis 15:55-71.

Volkow ND, Wang GJ, Fowler JS, Fischman M, Foltin R, Abumrad NN, Gatley SJ, Logan J, Wong C, Gifford A, Ding YS, Hitzemann R, Pappas N (1999) Methylphenidate and cocaine have a similar in vivo potency to block dopamine transporters in the human brain. Life Sci 65:PL7-PL12.

Wallace EA, Wisniewski G, Zubal G, vanDyck CH, Pfau SE, Smith EO, Rosen MI, Sullivan MC, Woods SW, Kosten TR (1996) Acute cocaine effects on absolute cerebral blood flow. Psychopharmacology (Berl) 128:17-20.

Wilson KC, Saukkonen JJ (2004) Acute respiratory failure from abused substances. J Intensive Care Med 19:183-193.

White FJ, Kalivas PW (1998) Neuroadaptations involved in amphetamine and cocaine addiction. Drug Alcohol Depend 51:141-153.

Woodward JJ, Compton DM, Balster RL, Martin BR (1995) In vitro and in vivo effects of cocaine and selected local anesthetics on the dopamine transporter. Eur J Pharmacol 277:7-13.

Zhang A, Cheng TP, Altura BT, Altura BM (1996) Acute cocaine results in rapid rises in intracellular free calcium concentration in canine cerebral vascular smooth muscle cells: possible relation to etiology of stroke. Neurosci Lett 215:57-59. 